ISSN 2338-5324 (print)

ISSN 2442-7276 (online)

Online di http://jkp.fkep.unpad.ac.id

DOI : $10.24198 / \mathrm{jkp}$

\title{
The Effect of Five-Finger Relaxation Technique to The Sleep Quality of Breast Cancer Patients
}

\author{
Rosliana Dewi ${ }^{1}$, Laili Rahayuwati ${ }^{2}$, Titis Kurniawan ${ }^{3}$ \\ ${ }^{1}$ STIKES Sukabumi, ${ }^{2,3}$ Faculty of Nursing Universitas Padjadjaran \\ Email: roslianadewi@ymail.com
}

Submitted: 5-4-2018 Accepted: 11-8-2018 Published: 11-8-2018

\begin{abstract}
Sleeping disorder is a symptom often suffered by breast cancer patients. To overcome it, five-finger relaxation technique is considered helpful. In previous research, this technique can be utilized to lower the level of anxiety and fatigue. This research, therefore, aims at identifying the effect of five-finger relaxation technique to the sleep quality of breast cancer patients. The research method used that of quasi experiment with pre-test and post-test control group design. The population included breast cancer patients within the service of the healthcare in Sekarwangi Hospital and R. Syamsudin SH Hospital. Sampling was done consecutively. The number of samples from control and intervention group were 30 people each. The intervention group received a standard hospital therapy and fivefinger relaxation technique divided in 15 sessions with 10-15 minutes time every other day for 1 month. Meanwhile, the control group received only a standard hospital therapy. The measurement tool was PSQI. The analysis used paired sample t-test and independent sample t-test. The result of the research has shown a difference in scores during pre-test and post-test of the sleep quality on both groups due to $p$ value $<0.05$. A difference has striken on the scores of sleep quality between control and intervention group with the latter having higher scores than the former. It can be concluded that five-finger relaxation technique does affect the quality sleep of breast cancer patients. The result of this research can be an additional intervention to decrease the symptoms suffered by breast cancer patients.
\end{abstract}

Keywords: Breast cancer, five-finger relaxation technique, sleep quality. 
Rosliana Dewi: The Effect of Five-Finger Relaxation Technique to The Sleep Quality of Breast Care

\section{Introduction}

Cancer is one of the main causes of morbidity and mortality worldwide. Globally, almost 1 of 6 deaths are due to cancer, around $70 \%$ of which occurs in countries with middleand low-income per capita. Further, WHO claimed that one of the most common cancerrelated deaths is breast cancer with 571.000 fatalities in 2015 (WHO, 2017).

Breast cancer is the most diagnosed cancer of all and the main cause of cancerrelated deaths for women worldwide. Based on the total of $23 \%$ cancer cases, $14 \%$ of which is of breast cancer, and around 1.15 million patients are diagnosed with invasive breast cancer every year. Moreover, about 40 million women died each year of it (Juvet et al., 2017).

According to Basic Health Research in 2013 , the prevalence of breast cancer in Indonesia reaches up to 0.5 to 1000 women. More than $80 \%$ breast cancer cases in Indonesia were on the advanced stage, where medication is found rare to be successful. Meanwhile, West Java is the third province with the highest number of breast cancer phenomena, which is 6701 people with $0.3 \%$ prevalence (The Ministry of Health RI, 2016). Breast cancer may affect the patient in some aspects, including physical (pain, helplessness, exhaustion, sleeping disorder, and disrupted mobility), psychological (full of uncertainty, anxiety, and depression), social (isolation from society and financial burden), and spiritual (guilt, inner conflict as to accepting and denying the fact of her being ill) (Lubis \& Hasnida, 2009); (Tirgari, Iranmanesh, Fazel, \& Kalantari, 2012). The crystal ball of it all leads the breast cancer patient to have lower life quality (Zou, $\mathrm{Hu}, \&$ McCoy, 2014).

The implementation of breast cancer is done through a series of medicational stages. The most common cancer treatments are surgery/incision, chemotherapy, radiational therapy, hormonal therapy, body immune therapy, and/or the combination of all. Although these types of treatment might recover the patient's condition, it might cause side effects as well as a set of physical and psychological symptoms (Mustian, Cole, Lin $\&$ Asare, 2016). Some of those conditions can even impair the patient's ability to obey medication protocols, perform daily activities, and maintain conventional life standards (Kwekkeboom, Chermin, Lee, \& Wanta, 2010).

Some of the symptoms most reported due to cancer and its medication include sleeping disorder, fatigue, pain, loss of physical abilities, sarcopenia, cachexia, and osteoporosis (Mustian, Cole, Lin, \& Asare, 2016). Among these, sleeping disorder is the most often suffered by breast cancer patients (Gehrman, Garland, Matura, \& Mao, 2016).

A cancer-diagnosed woman typically possesses a high sleeping disorder prevalence during treatment and recovery (Palseh, Ulusakarya, Tudela, \& Gerry, 2013); (Mustian, Cole, Lin, \& Asare, 2016). These patients thus have a higher risk of lower life quality, immune system, cognitive abilities, and abilities to perform daily routine.

A treatment, therefore, is necessary for this. Two approaches are being implemented; one is pharmacologically and the other is non-pharmacologically. The former approach includes Cognitive Behaviour Therapy (CBT), an effective non-pharmocological therapy to overcome problems related to sleeping disorder. It is a short-term therapy (12 to 20 sessions) that emphasize the importance of patient's thoughts in deciding what they feel and what they will do (Kwekkeboom, Chermin, Lee, \& Wanta, 2010); (Bower, Julienne E, 2008; Mendoza, Capafons, Gralow, Syrjala, \& Rodriguez, 2016; Mustaffa, Abu, \& Yusouf, 2012).

One of the applicable CBT form is relaxation technique. It is a technique which creates a relaxing condition to the autonomous nervous systems, leading up to a stabilized blood supply in muscles and decrease oxygen consumption, heart rates, perspiration, and muscle activities (Nugroho, 2016). Other relaxation techniques include autogenic training, progressive training and meditation (Lichstein, 1988).

One of the autogenic training techniques to overcome psychological disturbances is fivefinger relaxation technique. It is a process that utilizes the power of mind by moving the body for self-recovery and maintain health or a relaxed state of mind through inner communication involving all senses such as 
Rosliana Dewi: The Effect of Five-Finger Relaxation Technique to The Sleep Quality of Breast Care

smell, sight, and hearing (Davis \& McKay, 2008). Smeltzer and Bare also stated that five-finger relaxation technique is useful to handle anxiety of the patients because from a guided process of imagination will create a vision accepted by the receptions from all senses, creating a relaxed state of mind.

The evidence of how the five-finger relaxation technique is good for an alternative for breast cancer patients yet remains unidentified. Based on this result, the aim of this research is to identify the effect of five-finger relaxation technique toward the sleep quality of breast cancer patients in Sekarwangi Hospital and R. Syamsudin, SH Hospital.

\section{Method}

The research design is quasi experiment with pre-test and post-test control group design. The population in this research is all breast cancer patients within the healthcare service of Sekarwangi Hospital in Sukabumi District and R. Syamsudin Hospital, SH in the city of Sukabumi. The sampling technique is done consecutively with the number of samples as many as 60 respondents; 30 respondents for each intervention and control group. In intervention group, a hospital standard protocol is applied to breast cancer patients, in addition to five-finger relaxation technique. Meanwhile, in control group, a standard hospital protocol is applied without the fivefinger technique. The technique is done to the intervention group for one month every other day. The total of the sessions is 15 , with 1 session spending 10 to 15 minutes each.

The five-finger relaxation technique method can be done around 10 minutes through deep concentration and a relaxed state of mind. It can be done by pressing the thumb against the middle finger, while remembering the happiest moment of the patient's life. This is followed by pressing the thumb against the ring finger, while remembering the last time the patient had received appraisals. Lastly, the technique involves the thumb pressing against the ring finger, while remembering the most beautiful place the patient has ever visited (Keliat, et al., 2011).

The instrument used is Indonesiantranslated questionnaires; this is to measure the sleep quality using Pittsburgh Sleep Quality Index (PSQI) (Nugroho, 2016). The time of data sampling and experiment in this research was done from 23 December 2017 to 2 March 2018. The ethics of this research, before researching the selected samples, were adjusted upon the informed consent from the respondents that they are fully conscious to be involved in this research.

\section{Result}

A. Respondent's Characteristics

Table 1 Homogeneity Test of Respondent's Characteristics to the Intervention and Control Group

\begin{tabular}{|c|c|c|c|c|c|c|}
\hline \multirow[t]{3}{*}{ Characteristics } & \multicolumn{4}{|c|}{ Group } & \multirow[t]{3}{*}{$\mathrm{X}^{2}$} & \multirow[t]{3}{*}{$P$} \\
\hline & \multicolumn{2}{|c|}{ Intervention } & \multicolumn{2}{|c|}{ Control } & & \\
\hline & $f$ & $\%$ & $\mathrm{f}$ & $\%$ & & \\
\hline \multicolumn{7}{|l|}{ Age } \\
\hline$<40$ & 9 & 30 & 6 & 20 & 0.800 & 0.371 \\
\hline$>40$ & 21 & 70 & 24 & 80 & & \\
\hline \multicolumn{7}{|l|}{ Marital Status } \\
\hline Married & 22 & 73.3 & 24 & 80 & 0.373 & 0.542 \\
\hline Single & 8 & 26.67 & 6 & 20 & & \\
\hline \multicolumn{7}{|l|}{ IMT } \\
\hline$<18.50$ & 7 & 23.33 & 10 & 33.33 & 0.739 & 0.390 \\
\hline $18.50-24.99$ & 23 & 76.67 & 20 & 66.67 & & \\
\hline Employment & & & & & & \\
\hline
\end{tabular}


Rosliana Dewi: The Effect of Five-Finger Relaxation Technique to The Sleep Quality of Breast Care

\begin{tabular}{|c|c|c|c|c|c|c|}
\hline Employed & 4 & 13.33 & 4 & 13.33 & 0.001 & 1.000 \\
\hline Unemployed & 26 & 86.67 & 26 & 86.67 & & \\
\hline \multicolumn{7}{|l|}{ Education } \\
\hline Elementary & 16 & 53.33 & 18 & 60 & 0.694 & 0.707 \\
\hline Middle & 14 & 46.67 & 12 & 40 & & \\
\hline \multicolumn{7}{|c|}{ Duration of Illness } \\
\hline$<1$ year & 24 & 80 & 22 & 73.33 & 0.373 & 0.542 \\
\hline$>1$ year & 6 & 20 & 8 & 26.67 & & \\
\hline \multicolumn{7}{|l|}{ Stadium } \\
\hline Stadium 1 & 17 & 56.67 & 14 & 46.67 & 0.764 & 0.682 \\
\hline Stadium 2 & 8 & 26.67 & 11 & 36.67 & & \\
\hline Stadium 3 & 5 & 16.66 & 5 & 16.66 & & \\
\hline
\end{tabular}

The description of respondent's characterics from both control and intervention group are presented as follows.

Based on the table 4.1, the result of homogeneity test for all aspects of the respondent's characteristics shows $\mathrm{p}>0.05$.

This means that the respondent's characteristics in the control and intervention group are similar.

In detail, the characteristics in intervention and control group, respectively, show that they are generally aged more than 40 years old $(70 \%$ and 805$)$, maried $(73.33 \%$ and $80 \%$ ), have an IMT within range 18.50 $24.99(76.67 \%$ and $66.67 \%)$, are unemployed $(86.67 \%)$, elementary-school graduates $(53.33 \%$ and $60 \%)$, suffering cancer for more than 1 year $(80.00 \%$ and $73.33 \%)$ and in the first stage of cancer $(56.67 \%$ and $46.67 \%)$.

\section{B. Univariate and Bivariate Analysis}

\section{Sleep Quality}

The description result of mean score of sleep quality. The mean difference test during pre-test and post-test toward the score of sleep quality using paired sample t-Test and mean difference test control and intervention group uses Independent sample t-Test. The analysis result will be explained on table 4.2 as follows.

Table 4.2 shows that the mean and SD score of sleep quality in control group undergoes a decrease from 16.67 (1.184) to 15.40 (1.133). For the intervention group, it also undergoes a decrease from 16.97 (1.608) to 14.87 (1.332). Both groups undergo a decrease in PSQI scores that indicate that their sleep quality has gotten better.

Table 4.2 also shows a difference in pretest and posttest scores to the control group from 16.67 to 15.40 ( $p$ value $=0.000)$. For the intervention group, there is also a mean

Table 2 Test Results of Pre-Post with Paired Sample t-Test and Difference Test Results with t-Independent Test to the Scores of Sleep Quality

\begin{tabular}{|c|c|c|c|c|c|c|c|c|}
\hline PSQI Scores & \multirow{2}{*}{ Mean } & \multicolumn{3}{|c|}{ Paired Sample t-Test } & \multicolumn{3}{c|}{ Uji t-Independen } & \multirow{2}{*}{ Mean Diff. } \\
\cline { 3 - 8 } & & $\begin{array}{c}\text { Mean } \\
\text { Diff. }\end{array}$ & $\mathrm{t}$ & & $\begin{array}{c}\text { Mean } \\
\text { Diff. }\end{array}$ & $\begin{array}{c}\text { Mean } \\
\text { Marg. }\end{array}$ & $\mathrm{t}$ & \\
\hline Control Group & & & & & & & & \\
\hline Pre-Test & 16.67 & 1.27 & 5.917 & 0.000 & 1.27 & & & \\
\hline Post-Test & 15.40 & & & & & 0.83 & 2.338 & 0.023 \\
\hline $\begin{array}{c}\text { Intervention } \\
\text { Group }\end{array}$ & & & & & & & & \\
\hline Pre-Test & 16.97 & 2.10 & 7.367 & 0.000 & 2.10 & & & \\
\hline Post-Test & 14.87 & & & & & & & \\
\hline
\end{tabular}


Rosliana Dewi: The Effect of Five-Finger Relaxation Technique to The Sleep Quality of Breast Care

difference in pre-test and post-test scores from 16.97 to $14.87(\mathrm{p}$-value $=0.000)$. Both groups have improved, despite the significantly higher margin scores in intervention group than in control group $(\mathrm{p}$ value $=0.023)$.

\section{Discussion}

\section{A. Sleep Quality}

Sleeping disorder in breast cancer patients cover various kinds of sleeping disorder such as insomnia, restless leg syndrome, and sleep apnea. Although this might occur more often to female breast cancer patients, insomnia is among the most occurring.

In this research, both control and intervention group undergo an increase in sleep quality. However, the increase in intervention group is significantly higher than in control group. In control group, the increase occurs because the participants were given a standard hospital therapy that covers the recovery for general conditions such as blood transfusion, symptomatic treatment, and wound treatment from breast cancer.

The five-finger relaxation technique gives a positive impact to the sleep quality of breast cancer patients. This therapy gives a positive result when done routinely. The mechanism of autonomous nerves will be affected by emerging changes and occur during the relaxation or after. The technique also creates emotional responses and soothing effects, shifting the sympathetic dominant nervous system to be parasympathetic nervous system. The combination of deep breath technique and meditation done in five-finger relaxation technique may trigger the release of neurotransmitter NO (nitride oxide) which affects the performance of simple muscles to become more relaxed and stimulate the blood veins for vasodilatation. This will accelerate the work of blood supply to the body and produce more energy (Welz, 1991).

Muafiro also stated that the five-finger relaxation technique may lower the level of anxiety of cervix cancer patients with $\mathrm{p}$-value $=0.000 \quad(\mathrm{p}<0.05)$. Similarly, Banon also claims that the technique is effective to lower the level of anxiety of hypertension patients with significance value of $0.019(\mathrm{p}<0.05)$. It also gives positive impact as to improve sleep quality. The result of this research supports the argument saying that the fivefinger relaxation technique is effective to give a relaxing effect, provide comfort, lower anxiety level, and cause drowsiness (Bell, McLeod, Nelson, Fehnel, \& Zografos, 2011). The five-finger relaxation technique is also able to trigger alpha waves and increase delta waves during sleep. This will maintain a deep-sleep condition that minimizes the chance of the body from getting suddenly awaken at night (Tang, Liou, \& Lin, 2010).

Complementary therapy such as the fivefinger relaxation technique can be one of the management alternatives in improving sleep quality non-pharmacologically. One of the benefits of this therapy is that it reduces the risk of side effects to occur from hypnotic-sedative drugs, which might just worsen insomnia complaints. Therefore, it will help to reduce the patient's cost and increase her level of satisfaction and prevent complication of unsolved sleeping disorders from happening.

Therefore, the technique is effective for independent nursing treatment or done individually by patients and their family at home.

\section{Limitations}

In this research process, the daily activities of the respondents were not strictly observed and controlled. The activities were reported by the respondents themselves in a form of a log-book, and honesty was crucial.

In this research, many things have not been explored by the researcher, such as contributing factors to the sleep quality and such pain as psychosocial factor. Psychosocial factors like stress, anxiety, can be theoretically explained with the three observed symptoms.

\section{Nursing Implication}

This research has the affect to develop the field of nursing, specifically in handling the symptoms of sleep quality to breast cancer patients. This research proves that the intervention of the five-finger relaxation technique significantly improves sleep quality. It is expected that the research result can be a research material for the hospital in treating the breast cancer patients, particularly 
Rosliana Dewi: The Effect of Five-Finger Relaxation Technique to The Sleep Quality of Breast Care

those with sleeping disorder.

This research has shed a new light compared to previous research that only focuses on verifying one symptom individually. It has proven that five-finger relaxation technique is effective to overcome three symptoms in a way caused by the similar psychological issue.

\section{Conclusion}

The five-finger relaxation techniqe has a positive influence to the decrease of sleep quality to breast cancer patients.

\section{Advice}

A. For nursing field

The result of this research can be a reference to develop the field of nursing regarding the selection of intervention to improve sleep quality of breast cancer patients

\section{B. For nursing service}

Improving sleep quality needs a solid coordination, which is expected between one and another in Sekarwangi Hospital Sukabumi District and Hospital R Syamsudin, SH Sukabumi City, particularly in nursing the breast cancer patients. The result of this research can be a basis to develop the intervention of nursing to patients, especially in choosing the kind of treatment for breast cancer patients

\section{References}

Aini, R. N., \& Satiningsih. (2015). Ketahanan Psikologis Pada Perempuan Penderita Kanker Payudara. Jurnal Penelitian Psikologi, 3(3).

American Cancer Society. (2015). Cancer Facts \& Figures. Atlanta: American Cancer Society, Inc.

Ardiana, Negara, H.W, Sutisna, M.(2013). Analisis Faktor Risiko Reproduksi Yang Berhubungan Dengan Kejadian Kanker Payudara Pada Wanita. Jurnal Keperawatan Padjajaran.1(2).106-111.

Ardinata, D. (2007). Multidimensional Nyeri. Jurnal Keperawatan Rufaidah Sumatera Utara, 2(2).
Asmadi. (2008). Teknik Prosedural Keperawatan Konsep dan Aplikasi Kebutuhan Dasar Klien. Jakarta: Salemba Medika.

Banon, E., Dalami, E., \& Noorkasiani. (2014). Efektivitas Terapi Hipnotis Lima Jari untuk Menurunkan Tingkat Ansietas Pasien Hipertensi. Jurnal Keperawatan Poltekes Kemenkes III.

Bell , C., McLeod, L., Nelson, L., Fehnel , S., \& Zografos . (2011). Development and Psychometric Evaluation of a New PatientReported Outcome Instrument Measuring the Functional Impact of Insomnia. Quality of Life Research, 20, 1457-1468.

Black, J., \& Hawks, J. (2014). Keperawatan Medical Bedah : Manajemen Klinis Untuk Hasil Yang Diharapkan. Jakarta: Salemba Emban Patria.

Bower, Julienne E; (2008). Behavioral Symptoms in Patients with Breast Cancer and Survivors. Journal of Clinical Oncology, 28(5), 768-778.

Budiyanto, T., Ma'rifah, A. R., \& Susanti, P. I. (2015). Pengaruh Terapi Dzikir terhadap Insensitas Nyeri Pada Pasien Post Operasi Ca Mammae di RSUD Prof DR Margono Soekarjo Purwokerto. Jurnal Keperawatan Maternitas, 3(2), 90-96.

Buysse, D. J., Reynolds III, C. F., Monk, T. H., Berman, S. R., \& Kupfer, D. J. (1988). The Pittsburgh Sleep Quality Index: A New Instrument for Psychiatric Practice and Research. Psychiatry Research, 28, 193-213.

Cramer, H., Lauche, R., Langhorst, J., \& Dobos, G. (2013). Characteristics of Patients with Internal Diseases Who Use Reaxation Techniques as a Coping Strategy. Complementary Therapies in Medicine, 21, 481-486.

Davis, M. E., \& McKay, M. (2008). The Relaxation \& Stress Reduction Workbook. Oakland: CA. New Harbinger.

DeLaune, S., \& Ladner, P. (2010). Fundamentals of Nursing. USA: Delmar 
Rosliana Dewi: The Effect of Five-Finger Relaxation Technique to The Sleep Quality of Breast Care

Thomson Learning.

Evangelista, T., Widodo, D., \& Widiani, E. (2016). Pengaruh Hipnosis 5 Jari Terhadap Tingkat Kecemasan Pasien Sirkumsisi di Tempat Praktek Mandiri Mulyorejo Sukun Malang. Nursing News, 1(2).

Galvao, D. A., \& Newton, R. U. (2005). Review of Exercise Intervention Studies in Cancer Patients. Journal of Clinical Oncology, 23, 899-909.

Gartika, N. (2016). Pengaruh Foot Reflexiology Terhadap Intensitas Nyeri Pada Pasien Kanker Payudara di Rumah Sakit Umum Pusat Dr. Hasan Sadikin Bandung . Tesis: Universitas Padjadjaran.

Gartner, R., Jensen, N.-B., Nielsen, J., Ewertz, M., \& Kroman, N. (2009). Prevalence of and Factors Associated With Persistent Pain Following Breast Cancer Surgery. JAMA, 302(18), 1985-1995.

Gehrman, P. R., Garland, S. N., Matura, L. A., \& Mao, J. (2016). Insomnia in breast cancer: independent symptom or symptom cluster? Palliative and Supportive Care, 1-7.

Ghaddafi, M. (2011). Tatalaksana Insomnia dengan Farmakologi atau Non-Farmakologi. Universitas Udayana, Fakultas kedokteran, Denpasar.

Gibson, S. J., \& Farrel, M. (2004). A Review of Age Differences in the Neurophysiology of Nociception and the Perceptual Experience of Pain. The Clinical Journal of Pain, 20(4), 227-39.

Glare, P. A., Davies, P. S., Finlay, E., Gulati, A., \& Lemanne, D. (2014). Pain in Cancer Survivors. Journal of Clinical Oncology, 32(16), 1739-1749.

Green, C. R., \& Johnson, T. H. (2010). Cancer Pain : An Age-Based Analysis. Pain Medicine, 11, 1525-1536.

Gunten, C. F. (2011). Pathophysiology of Pain In cancer. J Pediatr Hematol Oncol, 33(1), S12-S18.
Guyton, A., \& Hall, J. (2014). Buku Ajar Fisiologi Kedokteran. Jakarta: EGC.

Heaton, K., \& Anderson, D. (2007). A Psychometric Analysis of the Epworth Sleepiness Scale. Journal of Nursing Measurement, 15(3), 177-187.

Irawan, E., Rahayuwati, L., \& Yani, D. I. (2017). Hubungan Penggunaan Terapi Modern dan Komplementer Terhadap Kualitas Hidup Pasien Kanker Payudara. Jurnal Keperawatan Padjadjaran, 5(1), 19-28.

Jamison, R. N., Edwards, R. R., Liu, X., Ross, E. L., \& Michna, E. (2013). Relationship of Negative Affect And Outcome of an Opoid Therapy Trial Among Low Back Pain Patients. Pain Parct, 13(3), 10-20.

Juvet, L. K., Thune, I., Elvsaas, I. K., Fors, E. A., \& Lundgren, S. (2017). The effect of exercise on fatigue and physical functioning inbreast cancer patients during and after treatment and at 6 months follow-up A metaanalysis. The Breast, 33, 166-177.

Kamelia. (2012). Konsep Diri Pada Wanita Penderita Kanker Payudara (Carsinoma Mammae). Skripsi, Institusi Agama Islam Negeri Sunan Ampel, Psikologi, Surabaya.

Kelliat, B. A. (2011). Keperawatan Kesehatan Jiwa Komunitas : CMHN (Intermediate Course). Jakarta: EGC.

Kemenkes RI. (2016). Bulan Peduli Kanker Payudara. InfoDatin.

Khasanah, K., \& Hidayati, W. (2012). Kualitas Tidur Lansia Balai rehabilitasi Sosial "MANDIRI" Semarang. Jurnal Nursing Studies, 1(1), 189-196.

Kroz, M., Reif, M., Glinz, A., Berger, B., \& Nikolaou, A. (2017). Impact of a combined multimodal-aerobic and multimodal intervention compared to standard aerobic treatment in breast cancer survivors with chronic cancer-related fatigue - results of a three-armed pragmatic trial in a comprehensive cohort design. BMC Cancer, 17, 166-176. 
Rosliana Dewi: The Effect of Five-Finger Relaxation Technique to The Sleep Quality of Breast Care

Kwekkeboom, K. L., Cherwin, C. H., Lee, J. W., \& Wanta, B. (2010). Mind-Body Treatments for the Pain-Fatigue Sleep Disturbance Symptom Cluster in Persons with Cancer. Journal of Pain and Symptom Management, 39(1), 126-136.

LeBourgeois, M. K., Giannotti, F., Cortesi, F., Wolfson, A. R., \& Harsh, J. (2005). The Relationship Between Reported Sleep Qualit and Sleep Hygiene in Italian and American Adolescents. Pediatrics, 115(1), 257-264.

Lichstein, K. L. (1988). Clinical relaxation strategies. Oxford: John Wiley \& Sons.

Lomeli, H. A., Olmos, I. P., Gutierrez, C. T., \& Moreno, C. B. (2008). Sleep Evaluation Scales and Questionnaires : A Review. Actas Esp Psiquiatr, 36(1), 50-59.

Lubis, N. L., \& Hasnida. (2009). Dukungan Sosial Pada Pasien Kanker, Perlukah ? Medan: USU Press.

Lukman, G., \& Harjanto, E. (2007). Tata Laksana Farmakologis Nyeri Kanker. Indonesian Journal of Cancer, 3, 121-123.

Meliala, L., \& Pinzon, R. (2007). Breakthrough in Management of Acute Pain. Dexa Media, 4(20), 151-160.

Montoya, P., Larbig, W., Braun, C., Preissl, H., \& Birbaunmer, N. (2004). Influence of Social Support and Emotional Context on Pain Processing and Magnetic Brain Responses in Fibromyalgia. Arthritis \& Rheumatism, 50(12), 4035-4044.

Munawaroh, K. (2017). Modifikasi Pro Self Pain Control Untuk Menurunkan Nyeri dan Meningkatkan Kemampuan Aktivitas Pada Pasien Kanker Kolorektal Yang Menjalani Kemoterapi. Tesis, Universitas Diponenoro, Fakultas Kedokteran, Semarang.

Mustaffa, M., Abu, S., \& Yusof, R. M. (2012). Effect of Cognitve Behaviour Approach in Anxiety for Cancer Patients Undergone Chemotherapy. International Journal of Fundamental Psychology \& Social Science, 2(4), 70-73.
Mustian, K. M., Cole, C. L., Lin, P. J., \& Asare, M. (2016). Exercise Recommendations For The Management of Symtoms Clusters Resulting From Cancer and Cancer Treatments. Seminars In Oncology Nurse, 32(4), 383-393.

Palesh, O., Ulusakarya, A., Tudela, E. O., \& Gerry, A. A. (2013). Sleep Disruption in Breast Cancer Pain Patients and Survivors. Journal of The National Comprehensive Cancer Network, 11, 1523-1530.

Parala-Metz, A., \& Davis, M. (2013). Cancer Pain. Cleveland Clinic Hematology Oncology, 1-13.

Pednault, S. K., Roemer, L., \& Orsillo, S. M. (2008). Efficacy of an Acceptance-Based Behavior Therapy fo Generalized Anxiety Disorder : Evaluation in A Randomized Controlled Trial. Journal of Consulting and Clinical Psychology, 76, 1083-1089.

Peters, K. R., Ray, L. B., \& Fogel, S. (2014). Age Differences in The Variability and Distribution of Sleep Spindle and Rapid Eye Movement Densities. PLOS ONE, 9(3), e91047.

Potter, P. A., Perry, A. G., Stockert, P., \& Hall, A. (2016). Fundamentals of Nursing. Singapore: Elsevier Inc.

Prasetyo, S. N. (2010). Konsep dan Proses Keperawatan Nyeri. Yogyakarta: Graha.

Rana, S., Gupta, R., \& Chaudhary, P. (2011). Cancer Pain Management : Basic Information for Young Pain Physicians. Indian J Palliat Care, 17(2), 127-130.

Rilla, E. V., Ropi, H., \& Sriati, A. (2014). Terapi Murottal Effektif Menurunkan Tingkat Nyeri Dibanding Terapi Musik Pada Pasien Pascabedah. Jurnal Keperawatan Indonesia, 17(2), 74-80.

Rose, J. H., Kypriotakis, G., \& Bowman, K. F. (2009). Patterns of Adaptation in Patients Living Long Term With Advanced Cancer. Cancer, 115(18), 4298-310. 
Rosliana Dewi: The Effect of Five-Finger Relaxation Technique to The Sleep Quality of Breast Care

Said, M. I. (2012). Hubungan Ketidaknyamanan : Nyeri dan Malodour Dengan Tingkat Stres Pada Pasien Kanker Payudara di RSKD Jakarta dan RSAM Bandar Lampung. Tesis: Fakultas Ilmu Keperawatan. UI.

Said, M. I. (2012). Hubungan Ketidaknyamanan : Nyeri dan Malodour Dengan Tingkat Stres Pada Pasien Kanker Payudara di RSKD Jakarta dan RSAM Bandar Lampung. Tesis: Fakultas Ilmu Keperawatan. UI.

Sander, M. A. (2011). Profil Penderita Kanker Payudara Stadium Lanjut Baik Lokal Maupun Metastasis Jauh di RSUP Hasan Sadikin Bandung. Farmasains, 1(2).

Sari, A. D., \& Subandi. (2015). Pelatihan Teknik Relaksasi Untuk Menurunkan Kecemasan Pada Primary Caregiver Penderita Kanker Payudara. Gadjah MAda Journal of Professional Psychology, 1(3), 173-192.

Savard, J., Ivers, H., Villa, J., Gingras, A. C., \& Morin, C. (2011). Natural Course of Insomnia Comorbid With Cancer : An 18-Month Longitudinal Study. Journal of Clinical Oncology, 29(26), 3580-3586.

Schubert, C., Hong, S., Natarajan, L., Mills, P., \& Dimsdale, J. (2007). The Association Between Fatigue and Inflammatory Marker Levels in Cancer Patients : A Quantitative Review. Brain, Behavior, and Immunity, 413427.

Singh, J. A., Gabriel, S., \& Lewallen, D. (2008). The Impact of Gender, Age, and Preoperative Pain Severity on Pain After TKA. Clin Orthop Relat Res, 466, 27172723

Smeltzer, S. C., \& Bare, B. G. (2010). Brunner $\&$ Suddarth's Textbook of Medical Surgical Nursing. Philadelphia: Lippincot.

Solehati, T., \& Kosasih, C. E. (2015). Konsep dan Aplikasi Relaksasi dalam Keperawatan Maternitas. Bandung: PT. Refika Aditama.

Somchock, J. (2012). Effect of Foot
Reflexiology on Pain Reduction in Older Thai People. Adelaide: Fliders University.

Stepanski, E. J., Walker, M. S., Scwartzberg, L. S., Blakely, J., Ong, J. C., \& Houts, A. C. (2009). The Relation of Trouble Sleeping, Depressed Mood, Pain and Fatigue in Patients With Cancer. Journal of Clinical Sleep Medicine, 5(2), 132-136.

Stone, P. C., \& Minton, O. (2008). CancerRelated Fatigue. European Journal of Cancer, 44, 1097-1104.

Tang, M. F., Liou, T. H., \& Lin, C. C. (2010). Improving Slep Quality for Cancer Patients : Benefits of A Home-Based Exercise Intervention. Support Care Cancer, 18, 13291339.

Tirgari, B., Iranmanesh, S., Fazel, A., \& Kalantari, B. (2012). Quality of Life and Mood State in Iranian Women Post Mastectomy. Clinical Journal of Oncology Nursing, 16(3), E-118-22.

Tocco, K., Rowder, C., \& VanNoord, M. (2015). Sleep Issues With Patients Receiving Hemodialysis. Nephrology Nursing Journal, 42(6), 531-537.

Ulumuddin, B. A. (2011). Hubungan Tingkat Stres dengan Kejadian Insomnia Pada Mahasiswa Program Studi Ilmu Keperawatan Universitas Diponegoro. Jurnal.

Welz, K. (1991). Autogenic Training: A Practical Guide in Six Easy Steps. Woodstock. GA 30188. Woodstock: GA 30188.

WHO. (2017). Cancer. WHO Media Centre. Witdiawati, Rahayuwati, L, \& Sari, S.P. (2017). Studi Kualitatif Pola Kehidupan Pasien Kanker Payudara. Jurnal Keperawatan Padjajaran. 5(1). 73-85.

Widyanti, F., \& Wardani, I. Y. (2013). Pengaruh Teknik Relaksasi Lima Jari Terhadap Tingkat Kecemasan Pasien Pre Operasi di RSUD dr. Soedarso Pontianak Kalimantan Barat.

Wulandari, I. S. (2016). Pengaruh Relaksasi 
Rosliana Dewi: The Effect of Five-Finger Relaxation Technique to The Sleep Quality of Breast Care

Autogenik Terhadap Kualitas Tidur Pasien Hemodialisa di Rumah Sakit Advent Bandung. Tesis, Universitas Padjadjaran, Fakultas Keperawatan, Bandung.

Yarbro, C. H., Wujcik, D., \& Gobel, H. B. (2011). Cancer Nursing. Burlington, MA:
Jones and Bartlett Publisher, LLC.

Zou, Z., Hu, J., \& McCoy, T. P. (2014). Quality of Life Among With Breast Cancer Living in Wuhan, China. International Journal of Nursing Sciences, 79-88. 